\title{
IAMJ
}

INTERNATIONAL

AYURVEDIC

MEDICAL JOURNAL

\section{ROLE OF UDUMBARADI TAILA YONIPICHU IN THE MANAGEMENT OF KAPHAJA YONIYVAPAD - A PILOT STUDY}

\author{
Sonali R Gaikwad ${ }^{1}$, Shreyes. $S^{2}$, Yogitha Bali M. R $^{3}$ \\ ${ }^{1}$ PG Scholar, Dept of Prasooti Tantra \& Stree Roga, Rajiv Gandhi Education Society's Ayurvedic Medical \\ College, Ron, Karnataka, India \\ ${ }^{2}$ Associate Professor, Dept of P.G Studies in Prasooti Tantra \& Stree Roga \\ Rajiv Gandhi Education Society's Ayurvedic Medical College, Ron, Karnataka, India \\ ${ }^{3}$ Professor, Dept of Shalya Tantra, Sushrutha Ayurvedic Medical College, Bangalore, Ayurveda \& Yoga \\ Consultant, AAYUSH- Multispeciality Ayurveda \& Integrated Healthcare, Bangalore, Karnataka, India
}

Corresponding Author:shrss02@gmail.com

\section{https://doi.org/10.46607/iamj0708112020}

(Published online: November 2020)

Open Access

(C) International Ayurvedic Medical Journal, India 2020

Article Received: 30/10/2020 - Peer Reviewed: 13/11/2020 - Accepted for Publication: 17/11/2020

Check for updates

\section{ABSTRACT}

Background: Vaginal discharge, commonly known as leucorrhea, is a physiological condition which happens in female reproductive system. More than $75 \%$ women experience leucorrhea during their lifetime and $45 \%$ of them has recurrence. Objectives: To assess the efficacy of Udumbaradi Taila Yoni Pichu in management of Kaphaja Yoni Vyapad. Design: This is a single blind pilot study. 20 female patients with the complaints of Kaphaja Yonivyapad (nonspecific leucorrhoea) from the Dept. of Prasooti tantra and Stree Roga OPD of Rajiv Gandhi educational society's Ayurvedic Medical College, Ron were included for the study. Patients were administered Udumbaradi Taila Yonipichu for 7 days and were assessed before and after the treatment and followed up on the $14^{\text {th }}$ day. Results: This pilot study showed statistically significant changes with Udumbaradi Taila Yonipichu in reducing the complaints of Kaphaja Yoni Vyapad such as Katishoola $(\mathrm{p}<0.001)$, Kandu $(\mathrm{p}<0.001)$, consistency of the Srava $(\mathrm{p}<0.001)$ and Srava Pramana (quantity of the discharge) $(\mathrm{p}<0.001)$. Conclusions: Udumbaradi Taila 
Yonipichu showed effectiveness in the management of Kaphaja yoni Vyapad with the reduction of Katishoola, Kandu, consistency of the Srava and Srava pramana after the treatment.

Keywords: Kaphaja Yonivyapad, Udumbaradi Taila, Pilot study, Streeroga

\section{INTRODUCTION}

Vaginal infection is one of the most common gynecological affections and vaginal discharge is one of the most common reasons for which women seek medical attention. ${ }^{[1]}$ Leucorrhoea is an abnormal vaginal discharge often associated with irritation and is non-hemorrhagic in nature. The discharge may be white, yellow or greenish in colour. It is a symptom of underlying pelvic pathology. It accounts for more than an estimated of 1/4th Gynec patients visits to Gynecologist. $^{[2]}$

Leucorrhoea is physiological when associated with various phases of the menstrual cycle. It is considered by changes seen in the vaginal epithelium; changes in the normal bacterial flora and $\mathrm{pH}$ of the vaginal secretion predispose to leucorrhoea. [3] But when it turns into the pathological condition it produces associated problems like low backache, itching and burning sensation of vulva, poor appetite, discomfort, general weakness, pain in both legs etc. ${ }^{[4]}$

Nonspecific Leucorrhoea a white discharge from the vagina may be physiological or pathological. It may also be noticed without any disease. Normally, vaginal discharge happens in regular variations of amount and consistency during the course of the menstrual cycle. A greater than usual amount is normal in pregnancy, and a decrease is to be expected after delivery, during lactation and after menopause. ${ }^{[5]}$

Globally, Leucorrhea occurs in $1-14 \%$ of all the women in the reproductive age group and is responsible for 5-10 million OPD visits per year. ${ }^{[6,7]}$ The prevalence of excessive vaginal discharge in India is estimated to be 30\%.3 The NFHS -3 results show that $11 \%$ of women in India report at least one reproductive health problem related to vaginal discharge. ${ }^{[8,9]}$

Causes of leucorrhoea include chronic illness, fatigue, malnutrition, emotional disturbance, unhygienic condition, improper diet, constipation and chronic retroverted uterus. ${ }^{[10]}$ Leucorrhoea usually presents with low backache, vulval itching, abdominal pain, pain in legs, general weakness and loss of appetite. It also affects psychology of the female unless treated properly. Health and efficiency of women are also affected. This psychological bearing makes it imperative for the physician to do his utmost for its relief. [11]

Leucorrhoea is not a disease but a symptom of lot many other diseases. But sometimes these symptoms become so severe that they overshadow the underlying cause and leucorrhoea itself enhances to a stature of disease. White discharge is a common problem woman experience and hesitate to seek the treatment. This occurs as a result of improper reproductive system and if not controlled on time, can progress to a chronic stage and lead to other problems. It can be due to infection with Trichomonas vaginalis, Candida albicans or mixed bacterial infections, chronic cervicitis, cervical dysplasia, malignancy, or due to senile vaginitis. These are treatable as well as preventable as $25 \%$ of infections are asymptomatic. ${ }^{[12]}$ Syndromic approach or management that is routinely followed in managing leucorrhoea will not be able to identify or treat these infections unless the clinical management algorithm includes treatment for such infections. In order to detect specific pathogens causing cervicitis laboratory testing is necessary to identify the organisms involved. The vaginal discharge flowchart leads to three treatment outcomes: no medical treatment; treatment for only vaginal infections caused by TV, BV and/or Candida spp. or treatment for vaginal, and cervical infections caused by NG and/or CT. In the majority of settings, abnormal vaginal discharge is highly indicative of a vaginal infection, thus all women presenting with 
vaginal discharge receive treatment for $\mathrm{TV}, \mathrm{BV}$ and Candida spp. ${ }^{[13]}$

Gynecological disorders have been detailed in Ayurvedic science as Yoni Vyapads' or the Yoni Rogas that are twenty in numbers. Kaphaj Yoni Vyapad is one such disorder among the twenty Yonivapads, which exhibits the Lakshanas such as Picchila Yonisrava and Yoni Kandu. This disorder being more common in women affects both the physical and psychological health. There are various types of treatment methods explained by the Acharyas for the management of Kaphaja Yoni Vyapad among which Yoni Pichu is one of its kind that has shown its effectiveness in managing other Yonivyapads. In the present study, an effort has been made to evaluate the effects of Yonipichu with Udumbaradi Taila in the management of Kaphaja Yonivyapad, one of the 20 Yonivyapad affecting most women due to the present lifestyle and improper dietary habits.

Methodology: This was a single pilot study. Twenty female patients with the complaints of Kaphaja yoni vyapad fulfilling the inclusion criteria from the O.P.D. Dept of Prasooti Tantra \& Streeroga, Rajiv Gandhi Educational Society's Ayurvedic Medical College \& PG Research Center, Ron were selected for the study. Patients with the complaints of vaginal discharge, itching and stickiness were included for the study and those with cervical or uterine malignancy, cervical erosion, candidiasis, bacterial, pregnant and lactating women and patients with systemic diseases like HTN, DM, tuberculosis and afflicted with infections like HIV, Syphilis, Herpes Genitalis, PID and Endocrinal abnormalities like hyper and hypo gonadism and hyper prolactinaemia were excluded. Ethical clearance was obtained from the Institutional Ethical Committee and Informed consent was obtained from all the patients. Data was collected from the special case proforma containing all the necessary details pertaining to the study.

Study Design: This was a pilot study with single group, pre and post-test design with 20 patients of Kaphaja Yoni Vyapad.

Intervention: This study was conducted for 14 days in which Udumbaradi Taila Yoni Pichu was administered for days and follow up was done on $14^{\text {th }}$ day. Patients were explained in detail about the treatment and assurance was given.

Poorvakarma: Pichu and Udumbaradi Taila was sterilized with the help autoclave. After voiding the urine, patient was advised to lie down comfortably in the lithotomy position with the help of nursing staff. Perineal region was cleaned with savlon and betadine solution and draped.

Pradhana Karma: Under aseptic precaution sterile Pichu soaked in Udumbaradi Taila was inserted in the vaginal canal with the help of index finger and thumb and with the help of swab holding forceps in such a way that the thread of Yoni pichu was made lying out of vagina which will facilitate its easy removal.

Paschat Karma: Yoni pichu was retained till patient gets the urge of micturition or 3-4 hours after insertion. It was removed by the patient herself by pulling out the tampon of Taila by sitting in squatting position.

Assessment Criteria: Both the subjective and objective parameters were assessed before and after the treatment.

Subjective Parameters: Katishoola, Consistency of Srava, Kandu

Objective Parameters: Srava Pramana (quantity of the vaginal discharge)

Table 1: Showing Grading of the Parameters

\begin{tabular}{|l|l|l|l|l|}
\hline Sl.No & & Parameters & Grading & Scoring \\
\hline Subjective Parameters & 1. & Katishoola & Absent & 0 \\
\hline & & & Mild & 1 \\
\hline & & & Moderate & 2 \\
\hline & & & Severe & 3 \\
\hline & 2. & Consistency of Srava & Watery & 1 \\
\hline
\end{tabular}




\begin{tabular}{|l|l|l|l|l|}
\hline & & & curdy & 2 \\
\hline & 3. & Kandu & Mild & 1 \\
\hline & & & Moderate & 2 \\
\hline Objective parameters & & & Severe & 3 \\
\hline & 4. & Srava Pramana & $1 \mathrm{pad} /$ day & 1 \\
\hline & & & $2-3 \mathrm{pad} /$ day & 2 \\
\hline
\end{tabular}

\section{Drug Formulation}

Udumbaradi Taila that was to be administered for Yoni pichu was prepared by collecting all the required ingredients from GMP certified store under the supervision and assistance of Department of Dravya Guna, Rasashastra \& Bhaishajyakalpana of Rajiv Gandhi Educational Society's Ayurvedic Medical
College \& PG Research Center, Ron. Acharya Sharangadhara has advised Udumbaradi Taila Yoni Pichu for the management of Kaphaja Yoni Vyapad in Sharangadhara Samhitha and the same was prepared as per the Taila Paka Vidhi of Charaka Chikitsa Sthana.

Table 2: Ingredients of Udumbaradi Taila

\begin{tabular}{|c|c|c|c|c|c|c|c|}
\hline SL No & Sanskrit Name & Botanical Name & Family & Rasa & Virya & Vipaka & Part used \\
\hline 1. & Udumbara & Fecus glomerate & Moraceae & Kashaya & Sheeta & Madhura & Stem bark \\
\hline 2 & Plaksha & Ficuslacar & Moraceae & Kashaya & Sheeta & Katu & Stem bark \\
\hline 3 & Vata & Ficusbengal ensis & Moraceae & Kashaya & Sheeta & Katu & $\begin{array}{l}\text { Ankur, } \\
\text { panchang }\end{array}$ \\
\hline 4 & Ashwatha & Ficusreligiosa & Moraceae & $\begin{array}{l}\text { Kashaya, } \\
\text { madhura }\end{array}$ & Sheeta & Katu & Stem bark \\
\hline 5 & Parish & Thespesiapop ulnea & malraceae & kashaya & Sheeta & Katu & Stem bark \\
\hline 5 & Jati & Jasminum officinale & Oleaceae & Tikta, Kashaya & Ushna & Katu & Stem bark \\
\hline 6 & Patol & Tricosanthesd ioica & Cucurbitceae & Tikta & Ushna & Katu & Phal \\
\hline 7 & Nimba & Azadiractain dica & Meliaceae & Tikta, Kashaya & Sheeta & Katu & Panchang \\
\hline 8 & Laksha & Laccifelacca & lacciferidae & kashaya & Sheeta & Katu & Panchang \\
\hline 9 & Shalmali & Shalmaliamal barica & Bombacaceae & Madhur & Sheeta & Madhura & Ras niryasa \\
\hline 10 & Palasha & Butea monosperma & Fabaceae & $\begin{array}{l}\text { Tikta, katu, } \\
\text { Kashaya }\end{array}$ & Ushna & Katu & Ras niryasa \\
\hline 11 & Dhataki & $\begin{array}{l}\text { Woodfordiafr } \\
\text { ucticosa }\end{array}$ & Lythraceae & Kashaya & Sheeta & Katu & Pushpa \\
\hline 12 & $T i l$ & Sesamumind icum & Pedalaceae & $\begin{array}{l}\text { Madhur, } \\
\text { Kashaya }\end{array}$ & Ushna & Madhura & Taila \\
\hline
\end{tabular}

\section{Preparation of Udumbaradi Taila}

Preparation of Coarse powder:

Equal parts of the ingredients were taken and made into coarse powder separately. The ingredients were mixed methodically to make a homogeneous mixture and used to prepare Kalka and Kwatha.

Preparation of Kwatha (decoction):

Kwatha was prepared by following the general rule of text. One part of coarse powder was added with 4 parts of potable water and subjected to heat on medium temperature, until the volume was reduced to $1 / 4$ th of its initial quantity. The contents were filtered, and the filtrate was used as liquid media in the preparation of Taila.

Preparation of Kalka (paste):

The coarse powder was taken and mixed with sufficient quantity of water to prepare the Kalka. 


\section{Taila Paka:}

\section{For Taila Paka}

As per Samhita, Kalka (Paste): Sneha (Tila Taila Sesame oil): Kwatha (Decoction) were taken in proportion of respectively. Tila Taila was made warm in vessel and then vessel was taken out from flame and increments of Kalka was added to Tila Taila and heated for some time. Kwatha was added to these contents and heating was continued on medium flame till the Samyak Snehapaka Siddhilakshanas of Mridupaka were obtained. Udumbaradi Taila thus obtained was filtered while hot and preserved in an airtight container.

\section{Results}

This was a single pilot study conducted on twenty patients of Kapahaja Yoni Vyapad with a prepost design for 14 days. Patients were assessed before and after the treatment. (Table 1)

Table 3: Showing Demographic data

\begin{tabular}{|c|c|c|c|}
\hline SI.No & & & \\
\hline \multirow[t]{3}{*}{1.} & Age group (years) & Number & \\
\hline & $21-30$ & 7 & $35 \%$ \\
\hline & $31-40$ & 13 & $65 \%$ \\
\hline \multirow[t]{4}{*}{2.} & Socio-economic background & & \\
\hline & Lower & 10 & $50 \%$ \\
\hline & Middle & 3 & $15 \%$ \\
\hline & Upper & 7 & $35 \%$ \\
\hline \multirow[t]{3}{*}{3.} & Habitat & & \\
\hline & Urban & 10 & $50 \%$ \\
\hline & Rural & 10 & $50 \%$ \\
\hline \multirow[t]{4}{*}{4.} & Diet & & \\
\hline & Mixed & 8 & $40 \%$ \\
\hline & Vegetarians & 10 & $50 \%$ \\
\hline & Eggetarians & 2 & $10 \%$ \\
\hline \multirow[t]{3}{*}{5.} & Sleep & & \\
\hline & Disturbed & 17 & $85 \%$ \\
\hline & Not disturbed & 3 & $15 \%$ \\
\hline \multirow[t]{4}{*}{6.} & Prakruti & & \\
\hline & Vatapitta & 10 & $50 \%$ \\
\hline & Pittakapha & 3 & $15 \%$ \\
\hline & Kaphapitta & 7 & $35 \%$ \\
\hline
\end{tabular}

Table 4: Results

\begin{tabular}{|c|c|c|c|c|c|c|c|c|c|}
\hline SI No. & Symptoms & Mean & Difference & $\%$ & SD & & SE & $t$ - Test & p-value \\
\hline \multicolumn{5}{|l|}{ BT } & \multicolumn{5}{|l|}{ AT } \\
\hline 1 & Katishoola & 2.95 & 1 & 1.95 & $48.75 \%$ & 1.3788 & 0.3085 & 4.46 & $<0.001$ \\
\hline 2 & Consistency of Srava & 3.35 & 1.75 & 1.6 & $40 \%$ & 1.1313 & 0.2531 & 4.46 & $<0.001$ \\
\hline 3 & Kandu & 2.95 & 1 & 1.95 & $48.75 \%$ & 1.3788 & 0.3085 & 4.46 & $<0.001$ \\
\hline 4 & Sravapramana & 2.3 & 1.35 & 0.95 & $23.75 \%$ & 0.6715 & 0.1503 & 4.46 & $<0.001$ \\
\hline
\end{tabular}

Katishoola: Changes in mean from 2.95 before the treatment to 1after the treatment with the difference of $1.95, \mathrm{p}<0.001$ showing significant reduction in
Katishoola with effectiveness of Udumbaradi Taila Pichu in Kaphaja Yoni Vyapad.

Consistency of Srava: Changes in mean from 3.35 before the treatment to 1.75 after the treatment with 
the difference of $1.6, p<0.001$ showing significant improvement in the yoni Srava with effectiveness of Udumbaradi Taila Pichu in Kaphaja Yoni Vyapad.

Kandu: Mean which was 2.95 before the treatment was reduced to 1 after the treatment with the difference of $1.95, \mathrm{p}<0.001$ showing reduction in Kandu with effectiveness of Udumbaradi Taila Pichu in Kaphaja Yoni Vyapad.

\section{Srava pramana:}

Change in mean from 2.3 before the treatment to 1.35 after the treatment with the difference of $0.95, \mathrm{p}$ $<0.001$ showing reduction in quantity of the Srava with effectiveness of Udumbaradi Taila Pichu in Kaphaja Yoni Vyapad.

\section{DISCUSSION}

Vaginal discharge, commonly known as leucorrhea, is a physiological condition which happens in female reproductive system. More than 75\% women experience leucorrhea during their lifetime and 45\% of them has recurrence. Nowadays, a much greater number of young people suffer from leucorrhea which hinders their ability to grow and develop to their full potential. Many people are still ignorant and unaware of prevent leucorrhea which threats their health not only for recent time but also for the future. ${ }^{[14]}$ A healthy woman is a promise of healthy family. The concept of healthy yoni has been asserted in various phases of woman's life from puberty to marriage to childbirth and thereafter. Kaphaja yonivyapad is one of the problems which ruin both physically and psychologically. Due to change in lifestyle, modern food habits of fast food, junk food women is unable to follow the rules of Dincharya, Rutucharya, Rajaswala, Rutumati and Sutikaparicharya which are explained by Aacharyas for women's health. Thus she is prone to various Yoni Rogas one of which is Yonigata Shewta Picchilsrava, Yonikandu, Yonigata Alpavedana which are the features of Kaphaja Yonivyapada and is neglected by women as minor symptoms. ${ }^{[15]}$ Ayurveda always treats the diseases from the root cause with its unique therapies to prevent and to avoid the recurrence of the diseases. Major ailments affecting the female reproductive system are the Yoni Vyapads which are said to be caused due to the indulgence of Mithya Ahara Vihara, Artava Dusti, Shukra Dushti and influence of daiva. Kaphaja Yonivyapad is one among the twenty Yonivyapads described by the Ayurveda Acharyas. Kaphaja Yoni Vyapad can be correlated to nonspecific leucorrohea based on its characteristic features. In Kaphaja yoni vyapad, intake of Mithya Ahara, Ati Snighda and Abhishyandi Ahara vitiates Yoni Pradesha leading to excess Sweta Srava which is Snigdha (unctuous), Pandu varna (whitish in colour) and Picchila (sticky in nature) associated with Kandu (severe itching). Acharya Sushruta has described Atisheeta Srava, Pandu Varna And Kandu as the Lakshanas of Kaphaja yoni vyapad. Whereas, Acharya Vagbhata adds yellowish discharge per vagina with or without mild pain in addition. Regarding the management of Kaphaja yoni vyapad, various unique therapies have been mentioned in Ayurveda, in which Yoni Pichu is one among them. In the present study, Udumbaradi Taila has been used for Yoni Pichu for the management of Kaphaja Yonivyapad. The present study included 20 female patients with the complaints of Kaphaja Yoni Vyapad who were administered Udumbaradi Taila Yonipichu for the management of the disease. Patients were examined and assessed before and after the treatment for Katishoola, consistency of Srava, Kandu and Srava Pramana and showed significant results in all the outcome measures with $p<0.001$. Among the 20 female patients, maximum number of patients were in the age group of 31-40 yrs, middle socio-economic status $(50 \%)$, most of them were from urban areas $(50 \%)$, Vegetarians $(50 \%)$, having disturbed sleep (80\%) and of Vatapitta Prakruti (50\%). Vulvovaginal symptoms such as discharge, itch, odour and discomfort are common complaints of women attending general practice, gynaecology and sexual health clinics. ${ }^{[16]}$ Lactobacillus-dominant flora is associated with vaginal $\mathrm{pH}$ in the range 3.6-4.5. [17] This is generally considered the normal vaginal $\mathrm{pH}$ in women of reproductive age. Elevated vaginal $\mathrm{pH}$ greater than 4.5 is associated with BV (characterised by overgrowth of anaerobic bacteria), which is in turn 
associated with vaginal discharge symptoms, preterm birth, increased transmission of sexually transmitted infections and pelvic inflammatory disease. Thus, it seems that maintaining a low $\mathrm{pH}$ in the vagina could potentially reduce the incidence of troublesome symptoms and infection of the genital tract. ${ }^{[18]}$

The normal vaginal $\mathrm{pH}$ is acidic that is 4.5, [19] alteration in this vaginal $\mathrm{pH}$ value leads to growth of organisms which causes white vaginal discharge. Vaginal secretion consists of tissue fluid, epithelialdebris, electrolytes, protein and lactic acid. $^{[20]}$ So excessive vaginal discharge causes imbalance of all these essential component, hence individual feel general weakness, body ache and back ache etc. ${ }^{[21]}$

In the management of these vaginal discharges, Commercial intravaginal menstrual tampons have been widely used by women since the 1930s. Billions of tampons are sold every year, with an estimated $50 \%$ to $70 \%$ of women in industrialized countries using them. Underlying public acceptance is the safety of tampons, which has been demonstrated repeatedly in studies involving microbiological analyses, gynecological examination, and subject evaluation. ${ }^{[22]}$ Sthanika Chikitsa or Local treatment plays very crucial role in the management of various gynaecological disorders. Ayurveda has described many therapies for the management of common gynecological disorders (Stree Roga) and Sthanika Chikitsa is one of them. Sthanika Chikitsa (local therapies) helps to relieve itching, burning pain, discharge and bad smelling. In Ayurveda there are various forms of local treatments such as Yoni Pichu, Yoni Dhupana, Yoni Dhavana, Yonilepana, YoniVarti, Kshar Karma and Agnikarma have been mentioned for the management of various gynaecological and obstetrical disorders. Although it is more of local treatment, but its effect is systemic too and capable of preventing complications of diseases. Yoni Pichu is one of the types of Sthanika Chikitsa where sterile medicated Pichu is kept inside the vagina for a specific period of time. "Vatartanam Cha Yoninam Sekabhyanga Pichu Kria" [23] This is one of the simplest presurgical procedure that ensures the continuous drug delivery to the target organ, another advantage is that there is no need of sophisticated instruments and trained expert rather than patient can do itself after a little instruction. Pichu (Tampoon) is made up of cotton swab wrapped with gauze piece and tied with long thread. It should be immersed in medicated oil or liquid. Oils are mostly preferred due to its retention ability. Circular and elongated Pichu is used for shallow and deep insertion inside vagina respectively Pichu should be kept for 5 to 6 hour up to retention of urine. ${ }^{[24,25]}$ Ayurveda classics describes the action of medicines in three ways i.e. Dravyaprabhava, Gunaprabhava and Dravyaguna prabhava. According to Sushruta, Pichu helps in Lekhana karma and thus, removes slough. In Yonipichu, mostly medicated Kashaya, Sarpi and Taila are used. These preparations have two main functions i. e. Shodhana (purification) and Ropana (healing). Its various mode of action will depend upon the various types of medicine that used, as different medicines have different action. Depending on the drugs Yonipichu can act as an antibacterial, controls vaginal discharges, helps in wound healing. Pichu helps the medicine to remain at that particular site for a longer period for better action. It improves the musculature tone of vaginal canal. ${ }^{\text {[26] }}$

The present study showed significant changes in the reduction of the complaints of Kaphaja yoni vyapad with the Udumbaradi taila administration for 7 days.

\section{CONCLUSION}

In this pilot study, with a single group and pre-post design, Udumbaradi Taila Yonipichu showed significant changes in the management of Kaphaja Yoni Vyapad with the reduction of Katishoola, Kandu, consistency of the Srava and Srava Pramana after the treatment. This was a very easy and a cost-effective treatment that could be carried out on OPD basis without any adverse effects. Future studies can contribute by conducting studies with larger sample size and randomized controlled studies to further evaluate the effects of the formulation. 


\section{REFERENCES}

1. Wang J. Bacterial vaginosis. Primary Care Update for Ob/Gyns. 2000;7(5):181-185. [PubMed] [Google

Scholar]

2. Sabaratnum, Drukumaran, Sivanesa VR, Alokananda C. Textbook of Adolescent gynecology, sexually active adolescent. 1999; 46(2):733.

3. Tabassum.K, Sayeeda Begum, Nishat Rais, Zulkifle. Analysis of Leucorrhoea manifestations-an observational case study. International Journal of Herbal Medicine 2014; 2 (2): 23-26

4. Desai, P., Monali, D., Malini, D., Hazra, M. 1993. Cytopathology of uterine cervix using the Bethesda system in 2800 screened individuals. J. of Obs. \&Gynec. of India, 2(403-407).

5. Fox KK, Behets FM. Vaginal discharge. How to pinpoint the cause. Postgraduate Medicine 1995; 98: 87-90, 93- 96, 101.

6. Mincy ML. Effectiveness of salt solution wash on Luecorrhoea among married women. Nurse. 2010;2(4):7-9.

7. National Centre for Health Statistics. National Ambulatory Medicine Care Survey. Available at www.cdc.com/ nchs/about/ major/ahcd/ahcd1.html. Accessed on 27 July 2016.

8. Rahman S, Bogaerts J, Rahman M, Razzak R, Nessa K, Reza M. Validity Assessment of Flowcharts for Syndromic Management of Vaginal Discharge; ICDDR, B: Centre for Health and Population Research Mohakhali, Dhaka 1212, Bangladesh. ICDDR, B Working Paper No. 1589.

9. Chellan R. Gynaecological morbidity and treatment seeking behavior in south India: evidence from RCHRHS Survey $1 \& 2$. Journal of Health and population in developing countries [serial on the internet]. 2004. Available at http://www.jhpd.unc. edu/. Accessed on 27 July 2016.

10. Meena Kumari Bimal. A Community Based Study to assess Leucorrhoea and Associated Factors of Leucorrhoea among Women of Reproductive Age Group (15-45years) in selected slums of Ludhiana, Punjab. Asian J. Nur. Edu. and Research. 2016; 6(2): 245-248. doi: 10.5958/2349-2996.2016.00047.1

11. Rudri Bai IM, Manju Deepthi and Dharmavijaya MN. Analysis of leucorrhoea in tertiary care hospital in rural Bangalore International Journal of Clinical Obstetrics and Gynaecology 2018; 2(4): 76-79.
12. Kharadi et al. Shwetpradar (Leucorrhoea): Etiopathpgenesis And Management With Herbal Drugs. World Journal of Pharmaceutical Research SJIF Impact Factor 8.074 Volume 8, Issue 7, 591-602.

13. Zemouri C, Wi TE, Kiarie J, Seuc A, Mogasale V, Latif A, et al. (2016) The Performance of the Vaginal Discharge Syndromic Management in Treating Vaginal and Cervical Infection: A Systematic Review and Meta-Analysis. PLoS ONE 11(10): e0163365. https://doi.org/10.1371/journal.pone.0163365

14. Rakhmilla, Lulu \& Fah, Lola \& Sofiatin, Yulia \& Widjadjakusuma, Anggraini \& Rosyada, Nur. (2016). Knowledge, Attitude, and Practice about Vaginal Discharge on School-Age Girls in Jatinangor Senior High School. OALib. 03. 1-9. 10.4236/oalib.1103130.

15. Pinge $\mathrm{CD}$ et. al., A Comparative Study of Shyamatrivruttadi kalka in Kapahaja Yonivyapat. International Journal of Ayurvedic Medicine, 2015, 6 (2), 183-193

16. French P. Sorting out vaginal discharge. Trends Urol Gynaecol Sex Health 2004; 9: 22- 7.

17. Boskey ER, Telsch KM, Whaley KJ, Moench TR, Cone RA. Acid production by vaginal flora in vitro is consistent with the rate and extent of vaginal acidification. Infect Immun 1999; 67: 5170- 5.

18. Morris M, Nicoll A, Simms I, Wilson J, Catchpole M. Bacterial vaginosis: a public health review. BJOG 2001; 108: 439- 50.

19. Dutta D C. TextBook of Gynaecology includig Contraception. Konar Harilal (ed.), 5th ed., New Central Book Agency Kolkatta, Delhi, 2008: p.6.

20. Dutta D C. TextBook of $G$ ynaecologyincluding Contraception. Konar Harilal (ed.), 5th ed., New Central Book Agency Kolkatta, Delhi, 2008: p.7.

21. Renuka M. Tenahalli. A Comparative Study of Amalaki Choornaalong with Madhuand Vata Twak Kashaya Yoni Pichu Dharana in the Management of Shweta Pradara. J Ayurveda Integr Med Sci 2017; 4:14-18. http://dx.doi.org/10.21760/jaims.v2i4.9322

22. Chase, D. J., Schenkel, B. P., Fahr, A. M., Eigner, U., \& Tampon Study Group (2007). A prospective, randomized, double-blind study of vaginal microflora and epithelium in women using a tampon with an apertured film cover compared with those in women using a commercial tampon with a cover of nonwoven fleece. Journal of clinical microbiology, 45(4), 12191224. https://doi.org/10.1128/JCM.02156-06 
23. Yadavji Trikamji Acharya, Charak samhita Chikisastan. 3rd ed. Varanasi Chaukhambha surbharati Prakashan. Chikitsa sthana, chapter, 30:61, p.637

24. Jaymala Shirke, editor. Ayurvediya Striroga vigyan, 1st ed, Pune: Tathagat Prakashan 2003 P.164.

25. Dhanashri H. Mahajan et.al, A critical review on Sthanik Chikitsa (local therapies) Adopted in Stree Roga, Int. J. Ayu. Alt. Med., 2014; 2(3):28-35.

26. Singh et al. 2020 Greentree Group Publishers (C) IJAPC Int J Ayu Pharm Chem 2018 Vol. 12 Issue 2 www.ijapc.com 199 [e ISSN 2350-0204]

\section{Source of Support: Nil}

\section{Conflict of Interest: None Declared}

How to cite this URL: Sonali R Gaikwad: Role Of Udumbaradi Taila Yonipichu In The Management Of Kaphaja Yoniyvapad - A Pilot Study. International Ayurvedic Medical Journal \{online\} 2020 \{cited November, 2020\} Available from:

http://www.iamj.in/posts/images/upload/4986 4994.pdf 